\title{
Selection for higher body weight in Nelore cattle is effective in achieving an increase of longissimus muscle area without reducing subcutaneous fat thickness
}

\section{Tiago Roque Pinheiro ${ }^{1}$, Maria Eugênia Zerlotti Mercadante ${ }^{1}$, Lucia Galvão de Albuquerque², Sarah Figueiredo Martins Bonilha ${ }^{1}$, Fábio Morato Monteiro ${ }^{1}$}

1 Instituto de Zootecnia, Centro APTA Bovinos de Corte, 14160-970 - Sertãozinho - SP, Brasil.

2 Universidade Estadual Paulista, Faculdade de Ciências Agrárias e Veterinárias, 14884-900 - Jaboticabal - SP, Brasil.

\begin{abstract}
The objectives of this study were to estimate heritabilities and genetic and phenotypic correlations between carcass traits measured by ultrasound and other economically important traits generally used as selection criteria in beef cattle and to estimate the genetic changes in the carcass traits as a result of selection for post-yearling weight. Carcass traits measured by ultrasound at two ages (12 and 18 months) and the correlation of these traits with weight, hip height and body condition score of males (yearling) and females (post-yearling) were analyzed. Multi-trait analysis was performed using the restricted maximum likelihood method under an animal model. To demonstrate the effect of selection for growth, phenotypic and expected breeding value means of the carcass traits and weights according to selection line (Nellore control line, selection line and traditional line) were estimated using records from animals born in the last 3 years (2006 to 2008). The heritability estimates were high for longissimus muscle area (LMA) at 12 and 18 months of age (0.47 and 0.40, respectively). For fat thickness measures, heritabilities ranged from 0.37 to 0.29 . Genetic correlations of the same trait between the two ages were high for LMA (0.95). The Nellore breed shows medium to high genetic variability in carcass traits measured by ultrasound at 12 and 18 months of age, and a greater response is expected if selection for backfat thickness is performed at about 12 months of age. Selection for higher body weight will lead to an increase of LMA at the two ages without reducing subcutaneous fat thickness.
\end{abstract}

Key Words: carcass traits, correlated responses, genetic correlation, ultrasound, Zebu cattle

\section{Introduction}

The longissimus muscle area (LMA), measured between the 12th and 13th rib, is an indicator of muscling, whereas fat thickness measures are indicators of finishing and meat quality. Ultrasound measures combined with live weight can be used to estimate carcass, lean and retail yield with average accuracy (Bergen et al., 1996; Greiner et al., 2003; Silva et al., 2003). Therefore, in vivo measurement of these traits significantly contributes to the genetic improvement of carcass traits.

In Brazil, for the purpose of genetic evaluation, ultrasound measurement of LMA and subcutaneous fat thickness in Nellore cattle raised on pasture should be carried out at 18 months of age (post-yearling) since, at this age, the animals present medium to high variability in these traits (Araújo, 2003). However, the number of animals in the herd is significantly higher at one year of age compared with subsequent ages, when the animals are already selected based on other criteria, such as weaning and yearling weights. In this respect, studies on the additive genetic variation in ultrasound-measured carcass traits of Zebu animals at young ages are scarce (Yokoo et al., 2008, 2010).
Growth traits are included as selection criteria in all beef cattle breeding programs, since the farmer is paid for carcass weight. However, since selection based on higher growth rates results in an increase of weight and height at all ages and fat deposition increases after the decline of muscle tissue growth, these traits might be antagonistic (Berg \& Butterfield, 1976). Studies involving Bos taurus animals have shown poor genetic correlations between body weight and fat thickness and between LMA and fat thickness, or even that these traits are independent (Stelzleni et al., 2002; Meyer et al., 2004). In Brazil, genetic correlations of low magnitude between body weight and fat thickness ( -0.01 to 0.20 ) and between LMA and fat thickness (0.02 to 0.06) have been reported for Bos indicus animals, suggesting that fat deposition does not depend on muscle growth (Yokoo et al., 2008, 2010; Lima Neto et al., 2009).

In order to provide data that could contribute to the development and implementation of Bos indicus genetic breeding programs including ultrasound-measured carcass traits, the first objective of the present study was to estimate heritability coefficients and genetic and phenotypic correlations between carcass traits measured by ultrasound at 12 and 18 months of age and other economically important 
traits generally used as selection criteria in beef cattle. The second objective was to estimate genetic changes in the carcass traits as a result of selection for weight.

\section{Material and Methods}

The data used were obtained from the Nellore selection lines of Centro APTA Bovinos de Corte, Instituto de Zootecnia. The selection experiment started in 1981 with the establishment of two lines of Nellore cattle: control and selection lines, followed by the traditional line that included bulls purchased outside the herd. The animals were selected based on their own performance within the contemporary group (line $\times$ year), i.e., weight adjusted for 378 days of age (W378) for males obtained after feedlot performance testing, and weight adjusted for 550 days of age (W550) for females obtained on pasture. Males and females with higher W378 or W550 were selected from the $\mathrm{NeS}$ and NeT lines, whereas males and females with a selection differential around zero were retained from the $\mathrm{NeC}$ line (Mercadante et al., 2003).

The animals were kept on pasture until 7 months of age, when they were weaned. After this period, males were subjected to a feedlot performance test. Females remained on pasture, except for those born in 2004, 2005 and 2008, which were also subjected to a feedlot performance test after weaning. After one year of age, males and females were kept at pasture, except for a small sample of males (about 30 animals per year born between 2006 and 2008), which received a high-energy feedlot finishing diet until reaching $4 \mathrm{~mm}$ of backfat thickness for slaughter. These differences in feed management (pasture and feedlot) were taken into account in the formation of the contemporary groups.

Images of LMA and backfat thickness (BF) were obtained by ultrasound between the 12th and 13th ribs, transversely over the longissimus muscle. Rump fat thickness (RF) was measured at the junction of the gluteus medius and biceps femoris muscles between the hook and pin bones. The images were obtained with a Pie Medical 401347-Aquila apparatus equipped with a $3.5 \mathrm{MHz}$ linear probe $(18 \mathrm{~cm})$. Vegetable oil was used for image acquisition to guarantee acoustic contact between the linear probe and body of the animal. The images were saved and subsequently analyzed using the Echo Image Viewer 1.0 (Pie Medical Equipment B.V., 1996), with a precision of one decimal place.

The initial data set of ultrasound-measured carcass traits consisted of 3,077 records from 1,172 animals born between 2003 and 2008, progeny of 78 sires and 551 dams. The data set of weight at selection (W378 and W550), hip height and body condition score contained records from 7,759 animals born between 1978 and 2008.
The data set of the carcass traits was divided into two standard ages (yearling and post-yearling): 12 months of age (LMA_12,BF_12, and RF_12) and 18months of age (LMA_18, BF_18, and RF_18). As yearlings, 652 animals (304 males and 348 females) born between 2006 and 2008, from 44 sires and 390 dams, divided into 18 contemporary groups, were evaluated. The mean age of the animals was $12.76 \pm 0.74$ months. Post-yearling, 718 animals (183 males and 535 females) born between 2004 and 2008, from of 67 sires and 426 dams, divided into 26 contemporary groups, were evaluated. The mean age was $19.89 \pm 0.75$ months. Of these, 425 animals were evaluated at the two ages (12 and 18 months).

The following data obtained at selection were evaluated: W378 of males $(n=3,447)$ and W550 of females $(N=3,544)$ born between 1978 and 2008; hip height at 12 months of age for males (HH378, N=2,646) and at 18 months for females (HH550), $\mathrm{N}=2$,797) born after 1985; body condition score at 12 months for males (BC378, $\mathrm{N}=2,347$ ) and at 18 months for females (BC550, N=2,656) born after 1987. Body condition was evaluated on a scale ranging from 1 to 9 , with 1 corresponding to extremely lean animals and 9 corresponding to extremely fat animals. However, since there were no records for classes 1 and 2, the scale ranged from 3 to 9 .

The least square method was used to evaluate the effect of sex on carcass traits. The model included the fixed effects of contemporary group defined by selection line (control, selection an traditional), year of birth and management (1 - pasture and 2 - feedlot) sex, age class of dam at calving $(3, \ldots, \geq 10$ years $)$ and age of animal as linear covariate.

The variance components and the expected breeding values (EBV) were estimated by the restricted maximum likelihood method using the WOMBAT program (Meyer, 2006). The relationship matrix contained 8,430 animals.

The (co)variance components of the carcass traits obtained at 12 and 18 months of age were estimated by multitrait analysis $(6 \times 6)$ under an animal model. For all traits (LMA_12,BF_12, RF_12,LMA_18,BF_18, and RF_18), the model included direct additive genetic random effects, fixed effects of contemporary group defined by selection line $(1,2$, and 3 ), year of birth $(2004, \ldots, 2008)$, management (1 and 2) and sex (1 and 2), age class of cow at calving, and age of the animal as a linear covariate.

The (co)variance components of the carcass traits (LMA_12, BF_12, RF_12 and LMA_18, BF_18, RF_18) and of the traits obtained at selection (W378, W550 or HH378, HH550 or BC378, BC550) were estimated by multi-trait analysis $(5 \times 5)$ under an animal model. To solve a problem of convergence in the multi-trait analysis, LMA_18, BF_18, RF_18, W378 and W550 were standardized by the respective 
standard deviation. The breeding value is shown on the original scale. For the traits obtained at selection, the models included direct additive genetic random effects, maternal permanent environmental effects (only for W378 and W550), fixed effects of contemporary group (selection line and year), month of birth and age class of dam at calving, and age of animal as a linear covariate.

To illustrate the effect of direct selection for growth on the carcass traits, adjusted phenotypic and EBV means, according to selection line (control, selection and traditional) were estimated by the least square method using a model of fixed effects similar to that described above. Only records of animals born in the last 3 years (2006 to 2008) were used. These animals have 5.7 of average generation coefficient, with a minimum of 4.1 and a maximum of 7.0 generations; the generation coefficient was calculated according to Koch et al. (1994): GC = [(GCS + GCD)/2]+1, in which GCS and GCD are the generation coefficients for the sire and dam, respectively, assuming that the animals born before 1981 were the zero generation.

\section{Results and Discussion}

Backfat thickness and RF were lower at 12 months of age and higher at 18 months, demonstrating that fat deposition is better evaluated at 18 months of age in animals of this breed raised on pasture (Table 1).

According to Berg \& Butterfield (1976), in cattle, the growth of females and males differs in terms of composition and distribution of empty body weight gain between tissues. The most marked difference occurs in carcass composition and is due to variations in the fattening process. Females

Table 1 - Summary of statistics of traits

\begin{tabular}{lcccc}
\hline Traits & Mean & SD & Minimum & Maximum \\
\hline W378, kg & 309.13 & 39.86 & 155.87 & 436.30 \\
W550, kg & 276.44 & 44.38 & 160.03 & 428.37 \\
HH378, cm & 131.50 & 5.18 & 100.00 & 147.00 \\
HH550, cm & 131.80 & 4.98 & 113.00 & 147.00 \\
BC378, score & 7.26 & 0.75 & 3.00 & 9.00 \\
BC550, score & 6.98 & 0.89 & 3.00 & 9.00 \\
LMA_12, cm ${ }^{2}$ & 42.18 & 10.84 & 16.50 & 71.40 \\
BF_12, mm & 0.93 & 0.77 & 0.00 & 4.50 \\
RF_12, mm & 3.06 & 1.52 & 0.00 & 12.80 \\
LMA_18, cm ${ }^{2}$ & 48.18 & 9.19 & 24.50 & 85.10 \\
BF_18, mm & 1.75 & 1.36 & 0.00 & 10.10 \\
RF_18, mm & 4.70 & 2.57 & 0.00 & 15.40 \\
\hline W378-
\end{tabular}

W378 - male weight adjusted for 378 days of age; W550 - female weight adjusted for 550 days of age; HH378 - male hip hight at selection; HH550 - female hip height at selection; BC378 - male body condition score at selection; BC550 female body condition score at selection; LMA_12 - yearling longissimus muscle area; BF_12 - yearling backfat thickness; RF_12 - yearling rump fat thickness; LMA 18 - post-yearling longissimus muscle area; BF_18 - post-yearling backfat thickness; RF_18 - post-yearling rump fat thickness. reach maturity earlier and therefore enter the fattening phase earlier and present a lower carcass weight than males.

In the case of the management system used here, males did not suffer the effects of postweaning dry-lot management since they continued to be subjected to feedlot performance tests, whereas most females $(90 \%)$ remained on pasture (Table 2). This fact would explain the higher mean BF and RF observed for males at 12 months of age and the higher means observed for females at 18 months, although the effects of environment and age are confounding factors. A decrease between 12 and 18 months of age in BF and RF of males was also observed, probably an effect of the growth phase characterized by muscle tissue high and fast deposition (Berg \& Butterfield, 1976) or even an effect of environmental transition from feedlot to pasture for great part of males. Meyer et al. (2004), evaluating carcass traits in male and female Hereford and polled Hereford animals aged 300 to 700 days, and Yokoo et al. (2008), studying Nellore animals from 450 to 599 days, found higher mean LMA values in males than females. Mean BF and RF were higher in females at the same age, a finding demonstrating that, if the environment is the same for the two sexes, females enter the fattening phase earlier and present lower muscle area.

The heritability estimates for the carcass traits at the two ages ranged from moderate to high (Table 3). The estimate obtained for LMA_12 (0.47) agrees with Yokoo et al. (2009), who also studied Nellore animals at two standard ages and estimated heritabilities of 0.46 for LMA_12, 0.29 for BF_12, and 0.34 for RF_12. These authors reported heritability estimates of $0.33,0.59$ and 0.55 for LMA_18, BF_18 and RF_18, respectively, which are higher than the fat thickness estimates obtained in the present study. Also in Brazil, Urbinati et al. (2010) estimated heritabilities of 0.31 for LMA, 0.16 for BF, and 0.22 for RF in Nellore animals at 15 months of age. These estimates are lower than those found in the present study. In a study conducted in Uruguay involving approximately 10,700 Angus cattle aged 18 months, heritabilities of 0.27 and 0.11 were estimated for

Table 2 - Least squares means by sex

\begin{tabular}{lcc}
\hline Traits $^{1}$ & \multicolumn{2}{c}{ Sex } \\
\cline { 2 - 3 } & Male & Female \\
\hline LMA_12, cm & $52.65 \pm 0.37 \mathrm{~b}$ & $33.49 \pm 0.37 \mathrm{c}$ \\
LMA_18, cm & $56.67 \pm 0.45 \mathrm{~b}$ & $46.85 \pm 0.33 \mathrm{c}$ \\
BF_12, mm & $1.30 \pm 0.04 \mathrm{~b}$ & $0.71 \pm 0.04 \mathrm{c}$ \\
BF_18, mm & $0.90 \pm 0.09 \mathrm{c}$ & $2.42 \pm 0.06 \mathrm{~b}$ \\
RF_12, mm & $4.16 \pm 0.07 \mathrm{~b}$ & $2.23 \pm 0.07 \mathrm{c}$ \\
RF_18, mm & $2.96 \pm 0.14 \mathrm{c}$ & $6.03 \pm 0.11 \mathrm{~b}$ \\
\hline
\end{tabular}

${ }^{1}$ Defined in Table 1.

b,c Mean values within a variable having different letters differ at $\mathrm{P}<0.05$. 
LMA and fat thickness, respectively. According to the authors, the genetic variation observed in these carcass traits is sufficient to include these traits in genetic breeding programs (Ravagnolo et al., 2010).

The heritability estimates obtained in the present study for the ultrasound-measured carcass traits show that Nellore animals present considerable genetic variation at a young age, i.e., at about 12 months. However, the heritability estimate for BF was higher at 18 months of age, whereas similar estimates were obtained for RF at the two ages. These results might be explained by the fact that the environment at 12 months of age is not favorable to the expression of genetic variation in $\mathrm{BF}$, as this age coincides with the end of the dry season.

The estimated genetic correlation between LMA_12 and LMA_18 was high (0.95 \pm 0.09$)$, suggesting that basically the same sets of genes with additive action act on the expression of LMA at the two ages (Table 3). The genetic correlations between the subcutaneous fat measures at 12 and 18 months of age ranged from 0.44 to 0.69 , suggesting that the expression of the trait differs in part. Since the environment was different at the two ages for most animals, genotype $\times$ environment interactions may have occurred.

Yokoo et al. (2009) reported a high genetic correlation (0.83) between LMA evaluated at two ages (12 and 18 months) in Nellore animals. The genetic correlations between subcutaneous fat measures evaluated at these ages were also high ( 0.94 for BF and 0.72 for RF). These high genetic correlations between ultrasound-measured carcass traits obtained at different ages indicate that this type of evaluation can be performed at a younger age, permitting the earlier selection and sale of animals.

The genetic correlations between LMA and the subcutaneous fat measures evaluated at the same age were almost all low at both 12 and 18 months of age (Table 3). These results suggest that selection for greater muscling, i.e., LMA, at 12 and 18 months of age will practically not alter fat deposition in the animals since these traits are basically independent.
Similar results for these two traits (LMA and subcutaneous fat) have been reported for Bos taurus animals studied in vivo, demonstrating that these traits are lowly correlated or even independent (Stelzleni et al., 2002; Meyer et al., 2004). In Brazil, Yokoo et al. (2008) and Lima Neto et al. (2009) reported genetic correlations of -0.04 to 0.06 and phenotypic correlations of 0.04 to 0.19 between LMA and fat thickness for Bos indicus animals, confirming that subcutaneous fat deposition is practically independent of muscle growth. It should be noted that the phenotypic correlations between the carcass traits measured by ultrasound at 12 and 18 months of age were all positive and presented low standard errors (Table 3).

The high genetic correlations between the two fat thickness measures (BF and RF) evaluated at the same age suggest that only one measure needs to be obtained. Meyer et al. (2004) reported values of 0.80 to 0.89 for this parameter in Bos taurus animals, in agreement with the results of the present study. Yokoo et al. (2008) and Lima Neto et al. (2009) also found high genetic ( 0.74 and 0.64$)$ and phenotypic ( 0.48 and 0.60$)$ correlations between the two subcutaneous fat measures.

The genetic correlations between weight and LMA, which were positive and of medium magnitude, suggest that selection for body weight will result in genetic changes that favor an increase of LMA_12 in males $(0.43 \pm 0.15)$ at the same age and in females $(0.52 \pm 0.13)$ at an older age (Table 4). In females, the genetic correlations are lower because of the difference in age between the measurement of the carcass traits and W550. Despite the high standard errors, the genetic correlation estimates confirm that selection based on weight will lead to a positive change in LMA_12 in males and females without reducing BF_12 or RF_12.

Meyer et al. (2004), studying carcass traits and weight in Bos taurus males and females separately, found positive genetic correlations between LMA and weight at about 12 months of age ( 0.44 for males and 0.41 for females). The genetic correlations between fat thickness measures and weight at about 12 months of age were mainly positive, but

Table 3 - Estimates of heritability (diagonal), and genetic (above diagonal) and phenotypic (below diagonal) correlations ( \pm s.e.) between yearling and post-yearling carcass traits

\begin{tabular}{lccrrr}
\hline Traits ${ }^{1}$ & LMA_12 & LMA_18 & BF_12 & BF_18 \\
\hline LMA_12, cm ${ }^{2}$ & $0.47 \pm 0.11$ & $0.95 \pm 0.09$ & $0.05 \pm 0.23$ & $0.19 \pm 0.20$ & $0.20 \pm 0.20$ \\
LMA_18, cm ${ }^{2}$ & $0.58 \pm 0.03$ & $0.40 \pm 0.09$ & $-0.07 \pm 0.23$ & $0.17 \pm 0.19$ & $-0.01 \pm 0.21$ \\
BF_12, mm & $0.28 \pm 0.04$ & $0.15 \pm 0.05$ & $0.29 \pm 0.10$ & $0.69 \pm 0.20$ & $0.88 \pm 0.11$ \\
BF_18, mm & $0.19 \pm 0.05$ & $0.23 \pm 0.05$ & $0.34 \pm 0.05$ & $0.37 \pm 0.09$ \\
RF_12, mm & $0.26 \pm 0.04$ & $0.13 \pm 0.05$ & $0.58 \pm 0.03$ & $0.32 \pm 0.05$ & $0.59 \pm 0.19$ \\
RF_18, mm & $0.16 \pm 0.05$ & $0.20 \pm 0.02$ & $0.26 \pm 0.05$ & $0.65 \pm 0.02$ & $0.34 \pm 0.10$ \\
\hline
\end{tabular}

${ }^{1}$ Defined in Table 1. 
Table 4 - Phenotypic $\left(r_{p}\right)$ and genetic correlation $\left(r_{g}\right)$ estimates between yearling carcass traits and growth traits

\begin{tabular}{|c|c|c|c|c|c|c|}
\hline \multirow[t]{2}{*}{ Traits $^{1}$} & \multicolumn{2}{|c|}{ LMA_12 } & \multicolumn{2}{|c|}{ BF_12 } & \multicolumn{2}{|c|}{ RF_12 } \\
\hline & $r_{p}$ & $r_{g}$ & $r_{p}$ & $r_{g}$ & $r_{p}$ & $r_{g}$ \\
\hline W378 & $0.55 \pm 0.03$ & $0.43 \pm 0.15$ & $0.31 \pm 0.04$ & $0.42 \pm 0.18$ & $0.30 \pm 0.04$ & $0.26 \pm 0.18$ \\
\hline НН378 & $0.36 \pm 0.05$ & $0.03 \pm 0.15$ & $0.26 \pm 0.05$ & $0.30 \pm 0.16$ & $0.20 \pm 0.05$ & $0.14 \pm 0.16$ \\
\hline HH550 & $0.36 \pm 0.05$ & $0.08 \pm 0.14$ & $0.16 \pm 0.05$ & $0.16 \pm 0.16$ & $0.12 \pm 0.05$ & $0.09 \pm 0.15$ \\
\hline ВС378 & $0.45 \pm 0.04$ & $0.67 \pm 0.18$ & $0.28 \pm 0.05$ & $-0.01 \pm 0.28$ & $0.25 \pm 0.05$ & $0.14 \pm 0.25$ \\
\hline BC550 & $0.31 \pm 0.05$ & $0.43 \pm 0.16$ & $0.09 \pm 0.05$ & $-0.25 \pm 0.23$ & $0.12 \pm 0.05$ & $0.25 \pm 0.21$ \\
\hline
\end{tabular}

${ }^{1}$ Defined in Table 1.

close to zero, ranging from 0.0 to 0.05 for males and females. In Brazil, Yokoo et al. (2010) also reported medium positive genetic correlations between weights from weaning to yearling and LMA in Nellore cattle and genetic correlations close to zero between these weights and subcutaneous fat thickness.

The genetic correlations between LMA_12 and heights were low, indicating that these traits are practically independent. The genetic correlations of BF_12 and RF_12 with height obtained for males were relatively low and presented high standard errors $(0.30 \pm 0.16$ and $0.14 \pm 0.16)$. Yokoo et al. (2010), studying Nellore animals at 12 months of age, concluded that taller animals accumulate less subcutaneous fat at the same age.

The body condition of males and females (BC378 and BC550), which is a subjective designation of body fat deposition, was genetically more highly correlated with LMA_12 (0.67 and 0.43, respectively) than RF (0.14 and 0.25 ) or BF (-0.01 and -0.25). Mainly in females, at this age, fat evaluation might be confounded with muscle volume, since Nellore animals present good musculature but not considerable subcutaneous fat thickness, a fact suggesting that animals with higher muscle volume have a better body condition.

The genetic correlation between LMA_18 and adjusted weight of females at selection (W550) was 0.62, showing that selection for weight will lead to an increase of LMA at this age. For males, the correlation between weight and LMA_18 was moderate (0.47), but still indicates that selection for W378 will increase LMA at 18 months of age. Stelzleni et al. (2002), for Brangus cattle, and Yokoo et al. (2010), for Nellore cattle, reported genetic correlations of 0.44 and 0.64 between post-yearling weight and LMA, in agreement with the present study.

The genetic correlations of W550 with BF_18 and RF_18 were $0.22 \pm 0.15$ and $0.17 \pm 0.16$, respectively. Although these values are relatively low, it can be assumed that there is no reduction in the breeding value for subcutaneous fat thickness in females selected for post-yearling weight. These results are intermediate between the values reported by Stelzleni et al. (2002) for Brangus cattle (0.42) and by Yokoo et al. (2010) for Nellore cattle (0.06 and 0.03). The genetic correlations of W378 with BF_18 and RF_18 were also positive ( $0.35 \pm 0.17$ and $0.23 \pm 0.19$, respectively).

Meyer et al. (2004), who studied carcass traits and weight separately in Bos taurus males and females, found positive genetic correlations between LMA and weight at about 19 months of age (0.41) in both males and females. The genetic correlations between fat thickness measures and weight at about 19 months of age were close to zero in males (0.01 and 0.00 for BF and RF, respectively) and females (-0.05 and -0.02 for BF and RF). In Brazil, Meirelles et al. (2010), analyzing Canchim animals at 19 months of age, suggested that selection for post-yearling weight should result in correlated genetic changes in LMA and fat thickness in view of the positive and favorable genetic correlations between weight and LMA $(0.62 \pm 0.16)$ and between weight and fat thickness $(0.57 \pm 0.23)$.

Table 5 - Phenotypic $\left(\mathrm{r}_{\mathrm{f}}\right)$ and genetic correlation $\left(\mathrm{r}_{\mathrm{g}}\right)$ estimates between post-yearling carcass traits and growth traits

\begin{tabular}{|c|c|c|c|c|c|c|}
\hline \multirow[t]{2}{*}{ Traits $^{1}$} & \multicolumn{2}{|c|}{$\mathrm{LMA}_{-} 18$} & \multicolumn{2}{|c|}{$\mathrm{BF}_{-} 18$} & \multicolumn{2}{|c|}{$\mathrm{RF}_{-} 18$} \\
\hline & $\mathrm{r}_{\mathrm{f}}$ & $\mathrm{r}_{\mathrm{g}}$ & $\mathrm{r}_{\mathrm{f}}$ & $\mathrm{r}_{\mathrm{g}}$ & $r_{f}$ & $r_{g}$ \\
\hline W378 & $0.28 \pm 0.06$ & $0.47 \pm 0.19$ & $0.31 \pm 0.07$ & $0.35 \pm 0.17$ & $0.05 \pm 0.08$ & $0.23 \pm 0.19$ \\
\hline W550 & $0.49 \pm 0.03$ & $0.62 \pm 0.15$ & $0.28 \pm 0.04$ & $0.22 \pm 0.15$ & $0.30 \pm 0.04$ & $0.17 \pm 0.16$ \\
\hline НН378 & $0.10 \pm 0.06$ & $0.08 \pm 0.16$ & $0.09 \pm 0.08$ & $-0.02 \pm 0.15$ & $-0.10 \pm 0.08$ & $-0.14 \pm 0.16$ \\
\hline HН550 & $0.26 \pm 0.04$ & $0.17 \pm 0.15$ & $0.10 \pm 0.05$ & $-0.19 \pm 0.15$ & $0.07 \pm 0.05$ & $-0.29 \pm 0.16$ \\
\hline BC378 & $0.20 \pm 0.06$ & $0.55 \pm 0.23$ & $0.31 \pm 0.07$ & $0.57 \pm 0.21$ & $0.03 \pm 0.08$ & $0.39 \pm 0.23$ \\
\hline BC550 & $0.32 \pm 0.03$ & $0.47 \pm 0.18$ & $0.26 \pm 0.04$ & $0.53 \pm 0.17$ & $0.31 \pm 0.04$ & $0.63 \pm 0.16$ \\
\hline
\end{tabular}

${ }^{1}$ Defined in Table 1. 
The genetic correlations between HH550 and the carcass traits indicate that selection of animals with greater hip height will favor LMA_18 (Table 5). However, animals selected for greater height will show a small reduction in subcutaneous fat deposition at 18 months of age, i.e., taller animals will present lower BF_18 and RF_18. Studying Nellore cattle at 20 months of age, Cucco et al. (2010) found genetic correlations of $-0.02 \pm 0.11,-0.13 \pm 0.12$ and $-0.11 \pm 0.10$ between height and LMA, BF and RF, respectively. Riley et al. (2002), using carcass data of Brahman animals obtained after slaughter, and Yokoo et al. (2009), using in vivo carcass data of Nellore animals, reported genetic correlations of -0.07 and 0.38 between height and BF, respectively. The major problem of the relationship between size and production is without doubt the greater maintenance requirement of larger animals, which, when reaching adult age, will require a greater feed supply to meet their maintenance and production requirements, especially breeder cows.

Positive and favorable genetic correlations were observed between the carcass traits and body condition of females (Table 5), in contrast to the correlations estimated for carcass measures obtained at 12 months of age (Table 4).

Genetic changes in traits that are not used as selection criteria, i.e., the correlated response resulting from selection for growth, depend on the heritability of the directly selected trait and of the correlated traits, as well as on the genetic correlation between these traits. The averages of EBV and phenotypic values (Table 6) for the traits used as selection criteria (W378 and W550) were higher in selection and traditional line animals than in the control line. There was also a difference in EBV for W378 and W550 between the selected lines, with the observation of higher values in the traditional line. This finding is probably due to the fact that the traditional line had received genetic material from other herds of the Nellore breed, in addition to its larger effective size.
For LMA_12, the EBV of the animals differed between the three lines, with the highest mean observed for animals of the traditional line. The EBV for BF_12 and RF_12 were lower in the control line, but did not differ between the selected lines. In general, as a correlated response to selection for growth, the EBV average for the carcass traits were higher in the two selected lines when compared with the control line. The phenotypic means of BF_12 and RF_12, and BF_18 and RF_18, presented a nonsignificant increase or decrease, when compared with the control line, confirming that fat deposition is not reduced in animals selected for weight.

The increase of EBV in animals of the selected lines (selection and traditional) compared with the control line resulted in an annual genetic gain of 0.14 and $0.12 \mathrm{~cm}^{2}$ in LMA at 12 and 18 months of age, respectively, and of only $0.02 \mathrm{~mm} /$ year in BF and RF at the two ages.

In a selection experiment conducted from 1960 to 1982 involving three selection lines and one control line of Hereford cattle, two selected based on weight gain and one selected based on weight gain and muscling score, Koch et al. (2004) observed that the selected herds presented higher market weights than the control herd, with a mean difference of $38.5 \mathrm{~kg}$. In addition, selected animals had greater LMA, without a difference in subcutaneous fat thickness, as observed in this study.

In Brazil, Silva et al. (2009) estimated genetic trends for ultrasound-measured carcass traits in Nellore herds selected for post-yearling weight and muscling score. The authors reported a significant genetic trend for post-yearling weight (1.85 kg/year), whereas the genetic trends for LMA, BF and RF were low and nonsignificant $\left(0.012 \mathrm{~cm}^{2} /\right.$ year, $0.003 \mathrm{~mm} /$ year and $0.012 \mathrm{~mm} /$ year).

In the present study, although genetic change in the carcass traits was positive at the two ages studied, greater genetic changes were observed for LMA at about 12 months of age. According to Koch et al. (2004), selection based on

Table 6 - Average of phenotypic (PV) and estimated breeding (EBV) values by selection lines

\begin{tabular}{|c|c|c|c|c|c|c|c|}
\hline \multirow[t]{2}{*}{$\overline{\text { Traits }^{1}}$} & \multirow[t]{2}{*}{$\mathrm{N}$} & \multicolumn{3}{|c|}{$\mathrm{PV}$} & \multicolumn{3}{|c|}{ EBV } \\
\hline & & $\mathrm{NeC}$ & $\mathrm{NeS}$ & $\mathrm{NeT}$ & $\mathrm{NeC}$ & $\mathrm{NeS}$ & $\mathrm{NeT}$ \\
\hline W378, kg & 344 & $274.50 \mathrm{~b}$ & $337.40 \mathrm{a}$ & $339.97 a$ & $-1.71 c$ & $51.68 b$ & $58.64 \mathrm{a}$ \\
\hline W550, kg & 366 & $256.90 \mathrm{c}$ & $315.50 \mathrm{~b}$ & $335.64 \mathrm{a}$ & $-0.26 c$ & $42.04 b$ & $48.46 a$ \\
\hline LMA_12, $\mathrm{cm}^{2}$ & 652 & $39.01 \mathrm{c}$ & $41.40 \mathrm{~b}$ & $45.75 a$ & $0.32 c$ & $3.49 b$ & 4.68a \\
\hline BF_12, mm & 650 & $0.78 b$ & $0.92 \mathrm{a}$ & $1.04 \mathrm{a}$ & $-0.06 b$ & $0.38 a$ & $0.42 \mathrm{a}$ \\
\hline $\mathrm{RF} \_12, \mathrm{~mm}$ & 650 & $2.81 b$ & $2.96 \mathrm{~b}$ & $3.44 \mathrm{a}$ & $-0.08 b$ & $0.43 a$ & $0.47 \mathrm{a}$ \\
\hline LMA_ $18, \mathrm{~cm}^{2}$ & 453 & $53.16 \mathrm{~b}$ & $55.04 \mathrm{ab}$ & $55.62 \mathrm{a}$ & $0.19 b$ & $3.37 \mathrm{a}$ & $3.59 a$ \\
\hline BF_18, mm & 453 & $2.03 \mathrm{a}$ & $1.78 \mathrm{a}$ & $1.86 a$ & $0.07 \mathrm{C}$ & $0.46 \mathrm{~b}$ & $0.63 a$ \\
\hline $\mathrm{RF} \_18, \mathrm{~mm}$ & 451 & $5.19 \mathrm{ab}$ & $4.74 b$ & $5.47 \mathrm{a}$ & $0.09 \mathrm{c}$ & $0.51 b$ & $0.77 \mathrm{a}$ \\
\hline
\end{tabular}

${ }^{1}$ Defined in Table 1. 
growth traits such as weaning or post-yearling weight itself is not sufficient to optimize genetic progress in weight and carcass quality in beef cattle, and other traits such as carcass and meat quality traits need to be included as selection criteria.

\section{Conclusions}

Carcass traits measured by ultrasound at 12 and 18 months of age shows considerable genetic variability in a little herd of Nellore, and a greater response is expected if selection for increased or reduced backfat thickness is performed at about 12 months of age. The genetic variation in longissimus muscle area and rump fat thickness is practically the same at the two ages. Selection for higher body weight will lead to an increase of longissimus muscle area at the two ages without reducing subcutaneous fat thickness.

\section{Acknowledgements}

The authors express their gratitude to Fundação de Amparo à Pesquisa do Estado de São Paulo (FAPESP) and to the Conselho Nacional de Desenvolvimento Científico e Tecnológico (CNPq) for the financial support.

\section{References}

ARAÚJO, F.R.C. The use of real-time ultrasound to estimate variance components for growth and carcass traits in Nelore cattle. 2003. 56f. Thesis (Master in Animal Science) University of California, Davis.

BERG, R.T.; BUTTERFIELD, R.M. New concepts of cattle growth. New York: John Wiley \& Sons, 1976. 240p.

BERGEN, R.D.; McKINNON, J.J.; CHRISTENSEN, D.A. et al. Prediction of lean yield in yearling bulls using real-time ultrasound. Canadian Journal of Animal Science, v.76, p.305-311, 1996.

CUCCO, D.C.; VARONA, L.; FERRAZ, J.B.S. et al. Herdabilidade das características de estrutura corporal e correlações genéticas e fenotípicas com as características de carcaça mensuradas por ultrassonografia em bovinos Nelore. In: SIMPÓSIO BRASILEIRO DE MELHORAMENTO ANIMAL, 8., Maringá. Anais... Maringá: Sociedade Brasileira de Zootecnia, [2010]. (CD-ROM).

GREINER, S.P.; ROUSE, G.H.; WILSON, D.E. et al. Prediction of retail product weight and percentage using ultrasound and carcass measurements in beef cattle. Journal of Animal Science, v.81, p.1736-1742, 2003.

KOCH, R.M.; CUNDIFF, L.V.; GREGORY, K.E. et al Genetic response to selection for weaning weight or yearling weight or yearling weight and muscle score in Hereford cattle: Efficiency of gain, growth and carcass characteristics. Journal of Animal Science, v.82, p.668-682, 2004.

KOCH, R.M.; CUNDIFF, L.V.; GREGORY, K.E. Cumulative selection and genetic change for weaning or yearling weight or for yearling weight plus muscle score in Hereford cattle. Journal of Animal Science, v.72, p.864-885, 1994.

LIMA NETO, H.R.; BERGMAN, J.A.G.; GONÇALVES, T.M. et al. Parâmetros genéticos para características de carcaça avaliadas por ultrassonografia em bovinos da raça Guzerá. Arquivo Brasileiro de Medicina Veterinária e Zootecnia, v.61, p.251-258, 2009.

MEIRELLES, S.L.; ALENCAR, M.M.; OLIVEIRA, H.N. et al. Efeitos de ambiente e estimativas de parâmetros genéticos para características de carcaça em bovinos da raça Canchim criados em pastagem. Revista Brasileira de Zootecnia, v.39, p.1437-1442, 2010.

MERCADANTE, M.E.Z.; PACKER, I.U.; RAZOOK, A.G. et al Direct and correlated responses to selection for yearling weight on reproductive performance of Nelore cows. Journal of Animal Science, v.81, p.376-384, 2003.

MEYER, K. "WOMBAT" - Digging deep for quantitative genetic analyses by restricted maximum likelihood. In: WORLD CONGRESS ON GENETICS APPLIED TO LIVESTOCK PRODUCTION, 8., 2006, Belo Horizonte. Proceedings... Belo Horizonte, [2006]. (CR-ROM).

MEYER, K.; JOHNSTON, D.; GRASER, H.U. Estimates of the complete genetic covariance matrix for traits in multi-trait genetic evaluation of Australian Hereford cattle. Australian Journal of Agricultural Research, v.55, p.195-210, 2004.

RAVAGNOLO, O.; BRITO, G.; AGUILAR, I. et al Genetic parameters for ultrasound live traits in pasture fed Angus cattle. WORLD CONGRESS ON GENETICS APPLIED TO LIVESTOCK PRODUCTION, 9., Proceedings... Leipzig, [2010]. (CR-ROM).

RILEY, D.G.; CHASE JR., C.C.; HAMMOND, A.C. Estimated genetic parameters for carcass traits of Brahman cattle. Journal of Animal Science, v.80, p.955-962, 2002.

SILVA, S.L.; FERRAZ, J.B.S.; MOURÃO, G.B. et al. Tendências genéticas para características de carcaça avaliadas por ultrassom em um rebanho Nelore. In: REUNIÃO ANUAL DA SOCIEDADE BRASILEIRA DE ZOOTECNIA, 46., 2009, Maringá. Anais... Maringá: Sociedade Brasileira de Zootecnia, 2009. (CD-ROM)

SILVA, S.L.; LEME, P.R.; PUTRINO, S.M. et al. Estimativa do peso e do rendimento de carcaça de tourinhos Brangus e Nelore, por medidas de ultra-sonografia. Revista Brasileira de Zootecnia, v.32, p.1227-1235, 2003.

STELZLENI, A.M.; PERKINS, T.L.; BROWN JR., A.H. et al. Genetic parameter estimates of yearling live animal ultrasonic measurements in Brangus cattle. Journal of Animal Science, v.80, p.3150-3153, 2002.

URBINATI, I.; VENTURINI, G.C.; CHUD, T.C.S. et al. Parâmetros genéticos e fenotípicos de peso corporal aos 450 dias de idade e características de carcaça de animais da raça Nelore. Tendências genéticas para características de carcaça avaliadas por ultrassom em um rebanho Nelore. In: REUNIÃO ANUAL DA SOCIEDADE BRASILEIRA DE ZOOTECNIA, 47., 2010, Salvador. Anais... Salvador: Sociedade Brasileira de Zootecnia, [2010]. (CD-ROM).

YOKOO, M.J.; LÔBO, R.B.; ARAÚJO, F.R.C. et al. Genetic associations between carcass traits measured by real-time ultrasound and scrotal circumference and growth traits in Nelore cattle. Journal of Animal Science, v.88, p.52-58, 2010.

YOKOO, M.J.I.; ALBUQUERQUE, L.G.; LÔBO, R.B. et al. Genetic and environmental factors affecting ultrasound measures of longissimus muscle area and backfat thickness in Nelore cattle. Livestock Science, v.116, p.147-154, 2008.

YOKOO, M.J.I.; ROSA, G.J.M.; MAGNABOSCO, C.U. et al. Efeitos genéticos que afetam as características de carcaça medidas por ultrassom, em duas diferentes idades, e suas correlações com outras características de importância econômica em rebanhos da raça Nelore. In: REUNIÃO ANUAL DA SOCIEDADE BRASILEIRA DE ZOOTECNIA, 46., 2009, Maringá. Anais... Maringá: Sociedade Brasileira de Zootecnia, 2009. (CD-ROM). 